\title{
CURRENT STATUS OF THE POPULATION OF EPIPACTIS PALUSTRIS (L.) CRANTZ (ORCHIDACEAE) IN THE WIELKOPOLSKA NATIONAL PARK
}

\author{
Magdalena KluZa-Wieloch, Mazgorzata WyrzyKiewicz-RaszewsKa
}

\begin{abstract}
M. Kluza-Wieloch, M. Wyrzykiewicz-Raszewska, Department of Botany, Poznań University of Life Sciences, Wojska Polskiego 71 C, 60-625 Poznań, Poland, e-mail: kluza@up.poznan.pl, malgorzata.raszewska@ gmail.com
\end{abstract}

(Received: October 11, 2016. Accepted: December 21, 2016)

\begin{abstract}
AвSTRACт. The aim of this study was to determine the current status of the population of marsh helleborine at a locality in the Wielkopolska National Park. Variability in generative shoots was analysed. Recorded results were compared with a study published in the 1990's, in which this locality was described. Since that time the area covered by that population has decreased; nevertheless, it exhibits characteristics of being in a good condition. In that population three forms of that species were reported: $\mathrm{f}$. palustris, f. longibracteata and f. ochroleuca. The greatest threat for the existence of that heliophilous orchid was connected with the overgrowing of its habitat, for this reason measures should be taken to prevent succession and encroachment of trees and shrubs to that area.
\end{abstract}

KeY WORDs: Epipactis palustris, Wielkopolska National Park, population, variability

\section{INTRODUCTION}

Marsh helleborine, belonging to the family Orchidaceae, is a protected species (RozPORZA.DZENIE... 2014), relatively frequently found throughout Poland (SzlachetKo \& Skakuj 1996, ZająC \& ZająC 2001). However, the number of its localities, both in Poland and throughout Europe, is systematically decreasing (KoRNAś 1976, ŻUKOWSKI 1976, JASIEWiCZ 1981, Zarzycki \& Szeląg 2006, TimChenko \& KuZIARIN 2009, Bilz et al. 2011, Grulich 2012). The degree of threat or even elimination of this species are assessed as very high (Michalik 1975, KowALEWSKA 1995, ŻUKOWSKI \& JACKOWIAK 1995, NOWAK 2002, KąCKI et al. 2003, JACKOWIAK et al. 2007, KLUZa-Wieloch \& MaciejewsKa-RutKowsKa 2015). This species completely died out in the area of Ojców (Pię́Koś-Mirkowa \& Mirek 2003). In the Lublin region it lost 70-99\% their original resources, while in most localities the surviving populations are limited in number (FijaŁKowski 1994). In the Pobrzeże and the Pojezierze Kaszubskie regions out of 42 localities reported in literature a total of 17 were found, of which only seven are relatively abundant (a loss of $60 \%$ localities; KowalewsKa 1995). In Poznań out of 18 localities reported from the first half of the $19^{\text {th }}$ century, by 1985 only seven were left (JACKOWIAK 1993). For these reasons marsh helleborine classified to the category of vulnerable species (V) throughout Poland (PięKoś-Mirkowa \& Mirek 2003, ZARZYCKI \& SZELĄG 2006).

The primary factor of threat for the population of this species is connected with human interference in natural ecosystems, causing adverse changes in hydrological conditions of its natural habitats (SzLAСНЕтко 1995). They are most frequently long-term works on drainage of peatbogs and wet meadows, as well as their intensive use or complete elimination of their use. In this manner the number and area of natural habitats potentially available for this plant are decreasing (Michalik 1975, Kornaś 1976, KowalewSKA 1995, SZLACHETKO 1995).

SAROSIEK $(1985,1990)$ stressed the need and necessity to conduct research aiming at the determination of resources and ecology of populations of protected, rare and threatened plant species. In the case of this group of plants each new piece of information is valuable, whether concerning their distribution, conditions of their occurrence, habitat requirements, variability of individual and group characteristics of the population. 


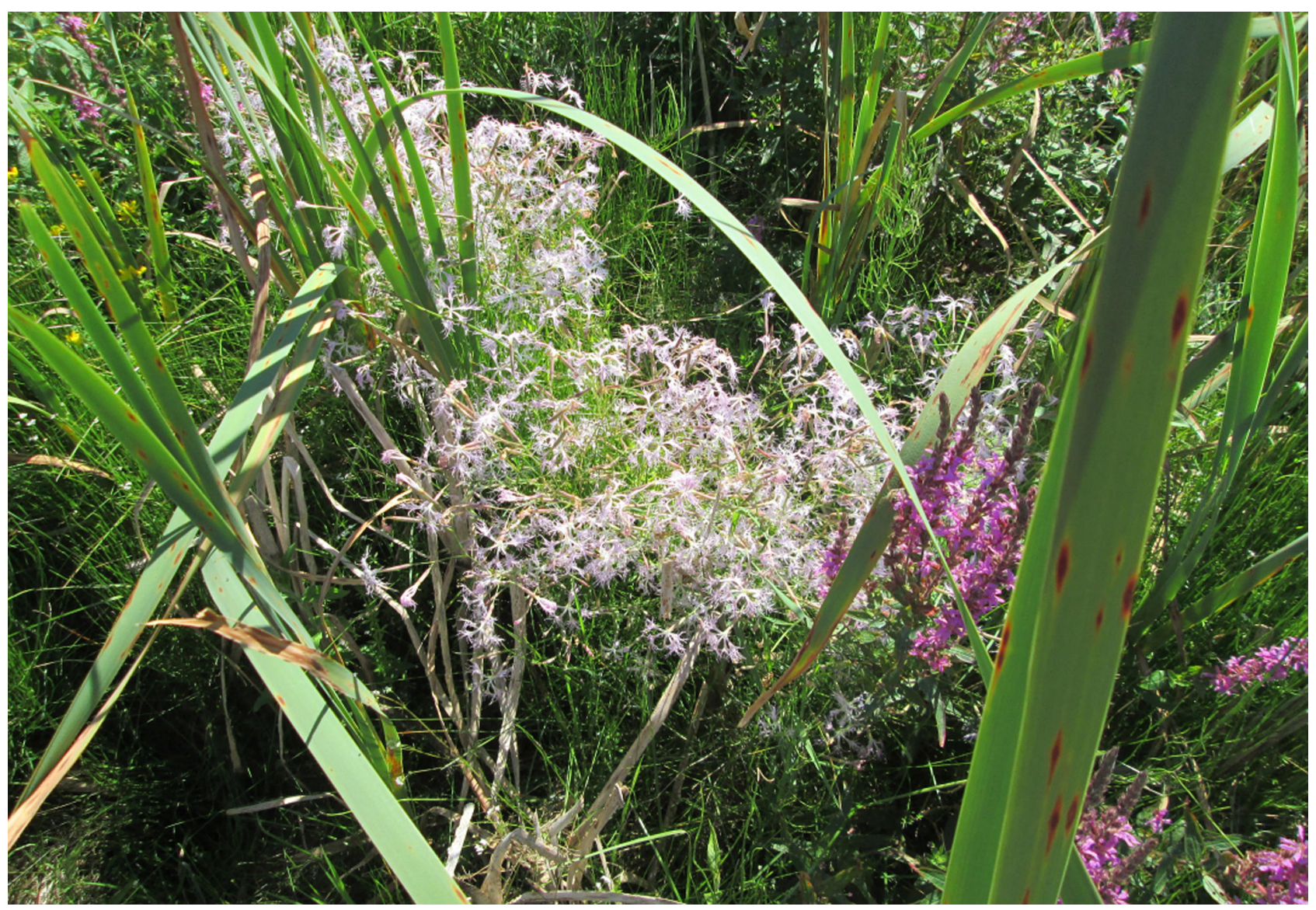

Fig. 1. Dianthus superbus in the Molinietum medioeuropaeum association

Table 1. Individual traits of generative shoots of Epipactis palustris in 2015 and 2016

\begin{tabular}{|c|c|c|c|c|c|c|c|}
\hline Year & Mean & Minimum & Maximum & Mediana & Variance & $\begin{array}{l}\text { Standard } \\
\text { deviation }\end{array}$ & $\begin{array}{c}\text { Variation } \\
\text { coefficient (\%) }\end{array}$ \\
\hline \multicolumn{8}{|c|}{ Height of plants $(\mathrm{cm})$} \\
\hline 2015 & 75.80 & 47.00 & 102.50 & 74.75 & 117.11 & 10.82 & 14.28 \\
\hline 2016 & 74.50 & 48.50 & 93.00 & 76.00 & 154.29 & 12.42 & 16.67 \\
\hline \multicolumn{8}{|c|}{ Length of inflorescence $(\mathrm{cm})$} \\
\hline 2015 & 17.87 & 9.50 & 26.50 & 18.50 & 16.22 & 4.03 & 22.54 \\
\hline 2016 & 16.45 & 7.00 & 23.00 & 17.00 & 19.56 & 4.42 & 26.88 \\
\hline \multicolumn{8}{|c|}{ Number of flowers } \\
\hline 2015 & 21.37 & 10.00 & 31.00 & 20.50 & 36.24 & 6.02 & 28.17 \\
\hline 2016 & 21.10 & 10.00 & 32.00 & 21.50 & 37.82 & 6.15 & 29.14 \\
\hline \multicolumn{8}{|c|}{ Number of leaves } \\
\hline 2015 & 8.60 & 8.00 & 10.00 & 8.50 & 0.46 & 0.67 & 7.84 \\
\hline 2016 & 8.50 & 6.00 & 11.00 & 8.50 & 1.09 & 1.04 & 12.26 \\
\hline \multicolumn{8}{|c|}{ Length of the largest leaf $(\mathrm{cm})$} \\
\hline 2015 & 13.84 & 4.50 & 17.10 & 14.00 & 5.53 & 2.35 & 16.99 \\
\hline 2016 & 14.37 & 9.00 & 18.00 & 14.60 & 4.16 & 2.04 & 14.20 \\
\hline \multicolumn{8}{|c|}{ Width of the largest leaf $(\mathrm{cm})$} \\
\hline 2015 & 3.08 & 2.20 & 4.70 & 2.95 & 0.30 & 0.54 & 17.64 \\
\hline 2016 & 3.75 & 2.60 & 4.90 & 3.95 & 0.45 & 0.67 & 17.93 \\
\hline \multicolumn{8}{|c|}{ Length of bracteole $(\mathrm{cm})$} \\
\hline 2015 & 3.09 & 1.80 & 5.50 & 2.90 & 0.73 & 0.85 & 27.60 \\
\hline 2016 & 3.30 & 1.50 & 4.60 & 3.50 & 0.70 & 0.83 & 25.29 \\
\hline \multicolumn{8}{|c|}{ Width of bracteole $(\mathrm{cm})$} \\
\hline 2015 & 0.60 & 0.50 & 0.70 & 0.60 & 0.01 & 0.08 & 12.82 \\
\hline 2016 & 0.60 & 0.40 & 0.80 & 0.60 & 0.01 & 0.10 & 16.95 \\
\hline
\end{tabular}



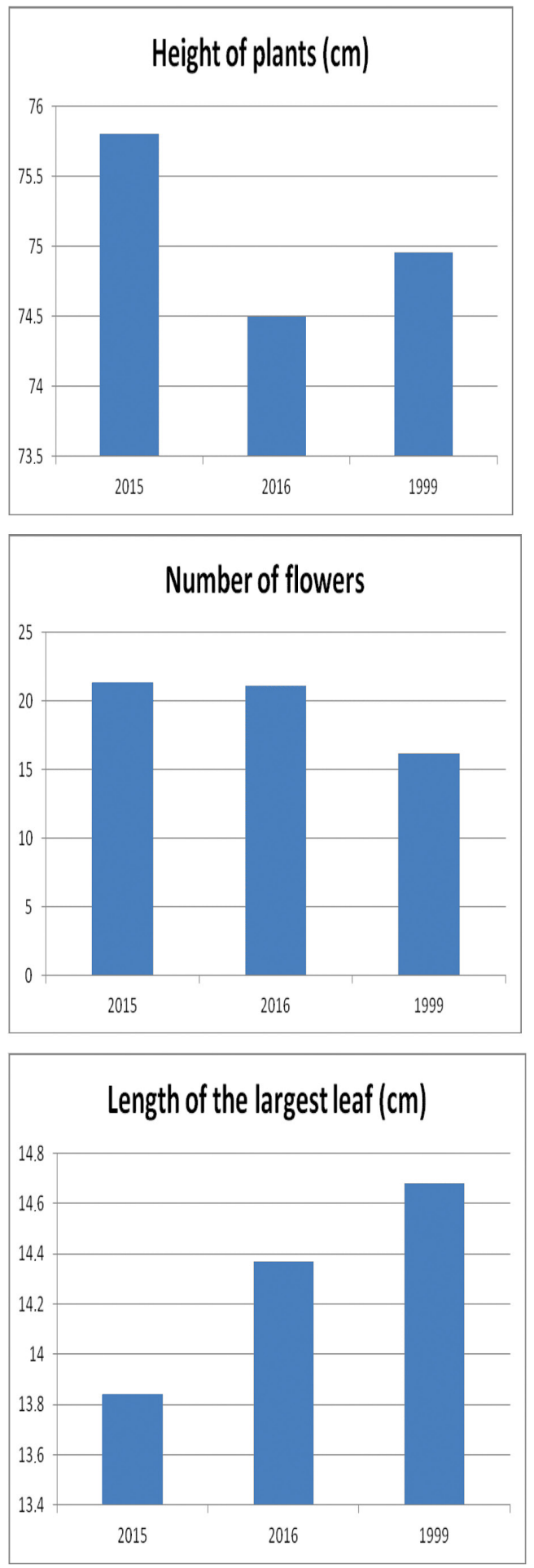
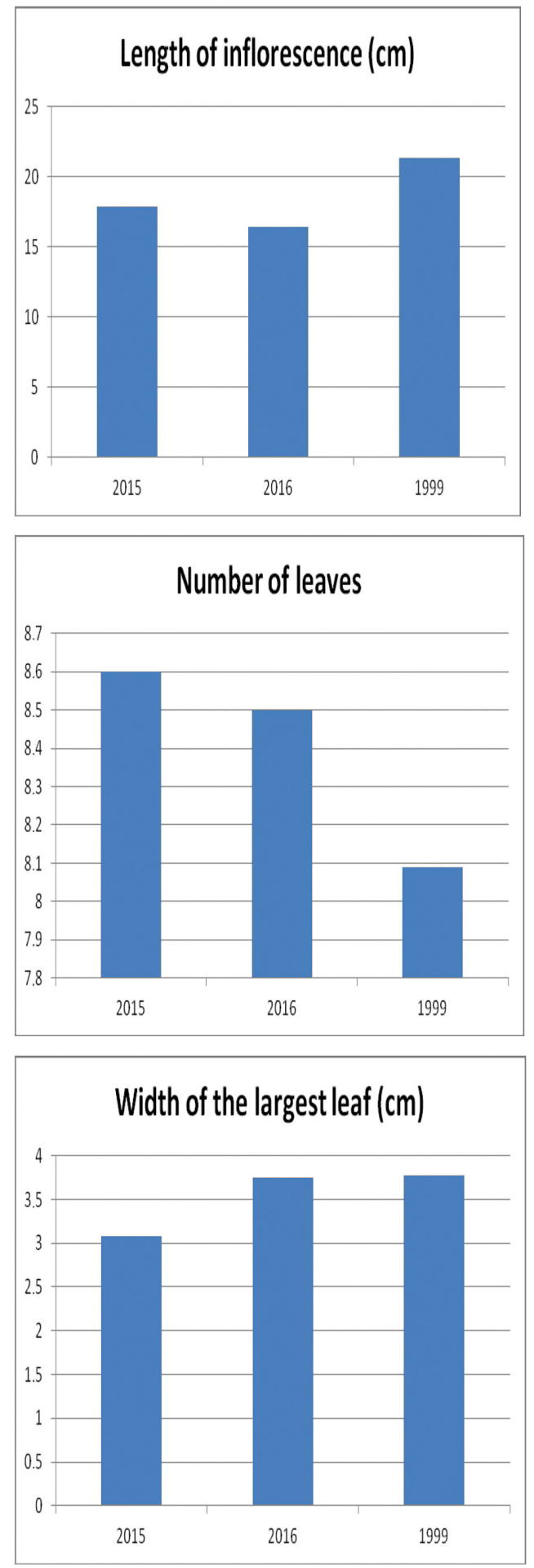

Fig. 2. Distribution of means: a) plant height, b) length of inflorescence, c) number of flowers, d) number of leaves, e) length of the largest leaf, f) width of the largest leaf, in the years of observations 2015-2016 and in 1999 (ANTKOwIAK \& PANKROS 2000)

The aim of this study was to prepare a floristic note on the current condition of the marsh helleborine population in the Wielkopolska National Park and to identify its present threats.

\section{MATERIAL AND METHODS}

The object of this study was the population of marsh helleborine (Epipactis palustris), located in Łódź in the Wielkopolska National Park. The position of the locality together with a respective map was given in a study by AntKowiak \& Pankros (2000). Analyses were conducted in the years 2015 and 2016, each 

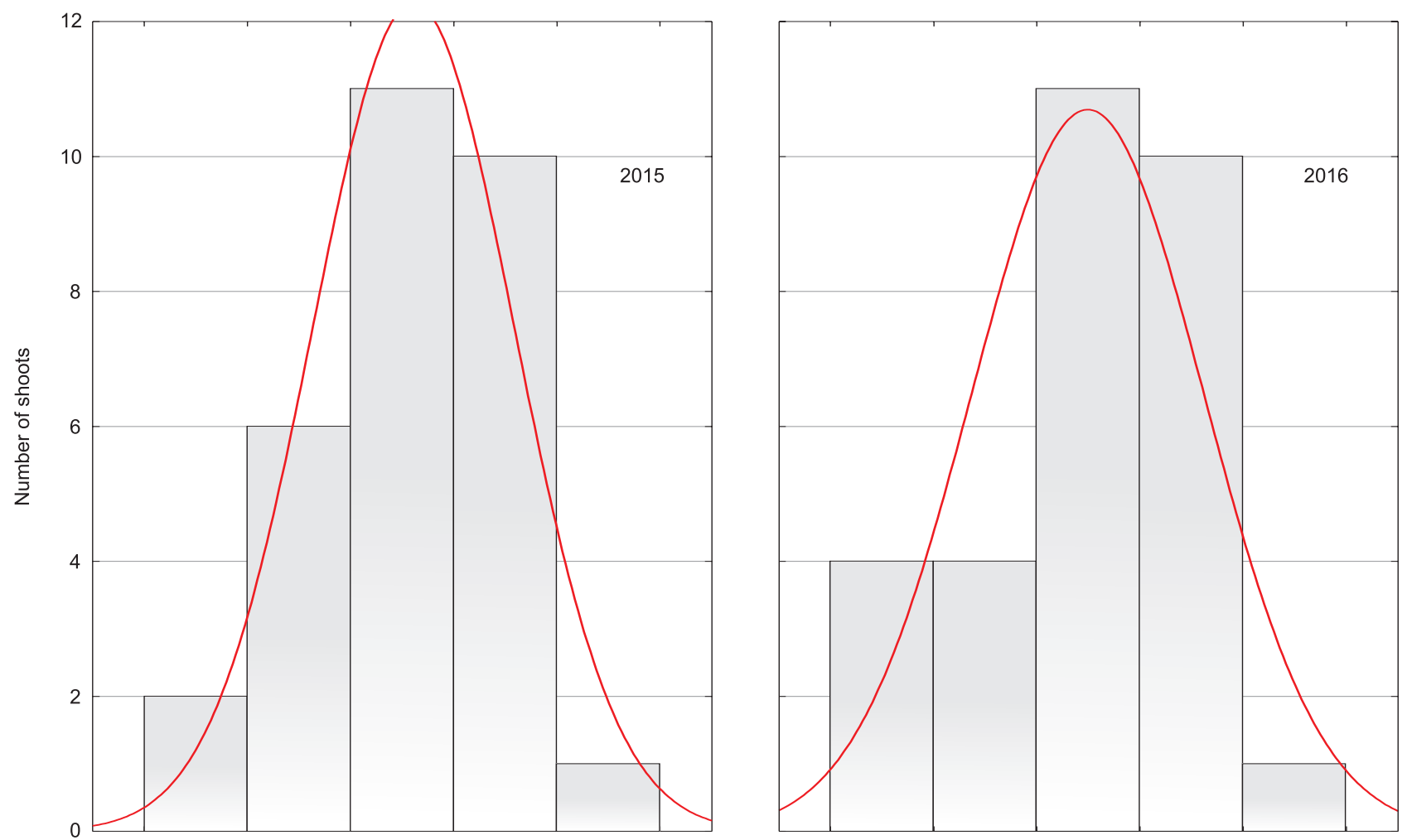

Fig. 3. A histogram of height for flowering shoots in the years of the study 2015-2016

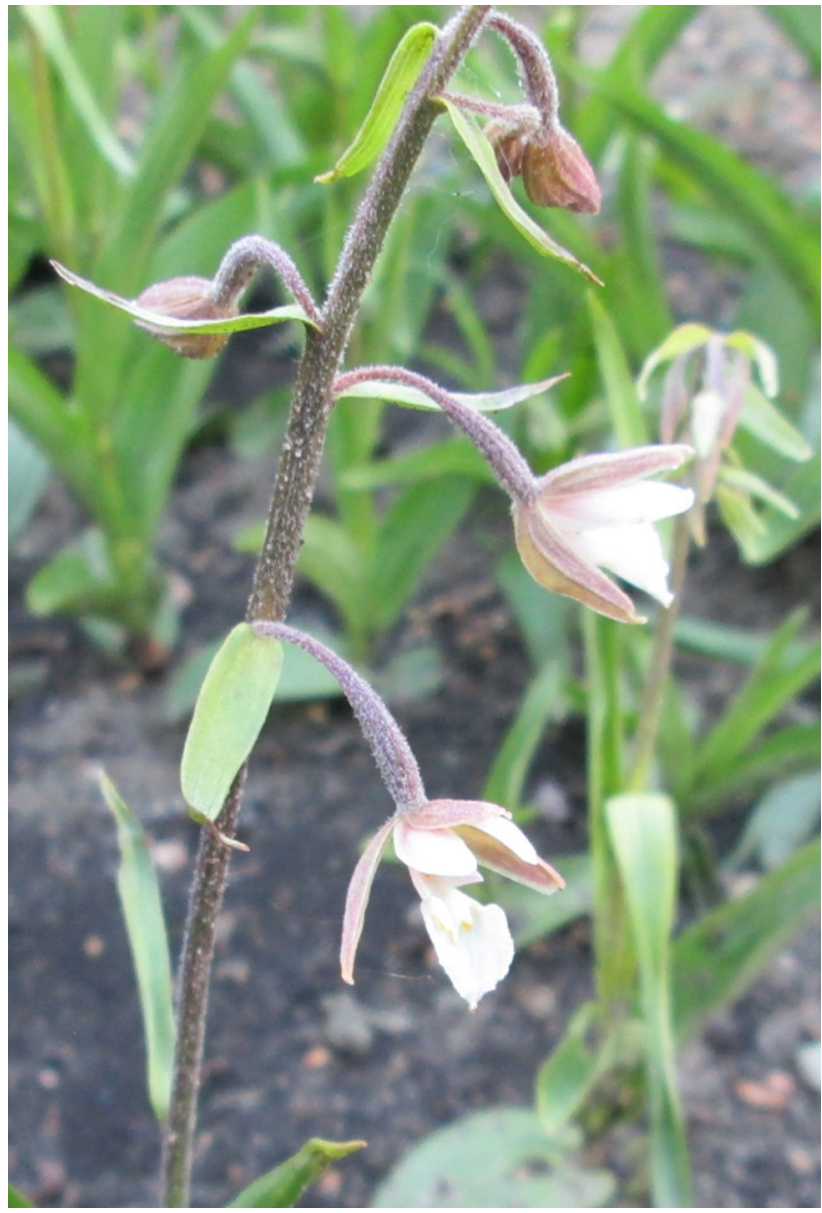

Fig. 4. Epipactis palustris f. palustris

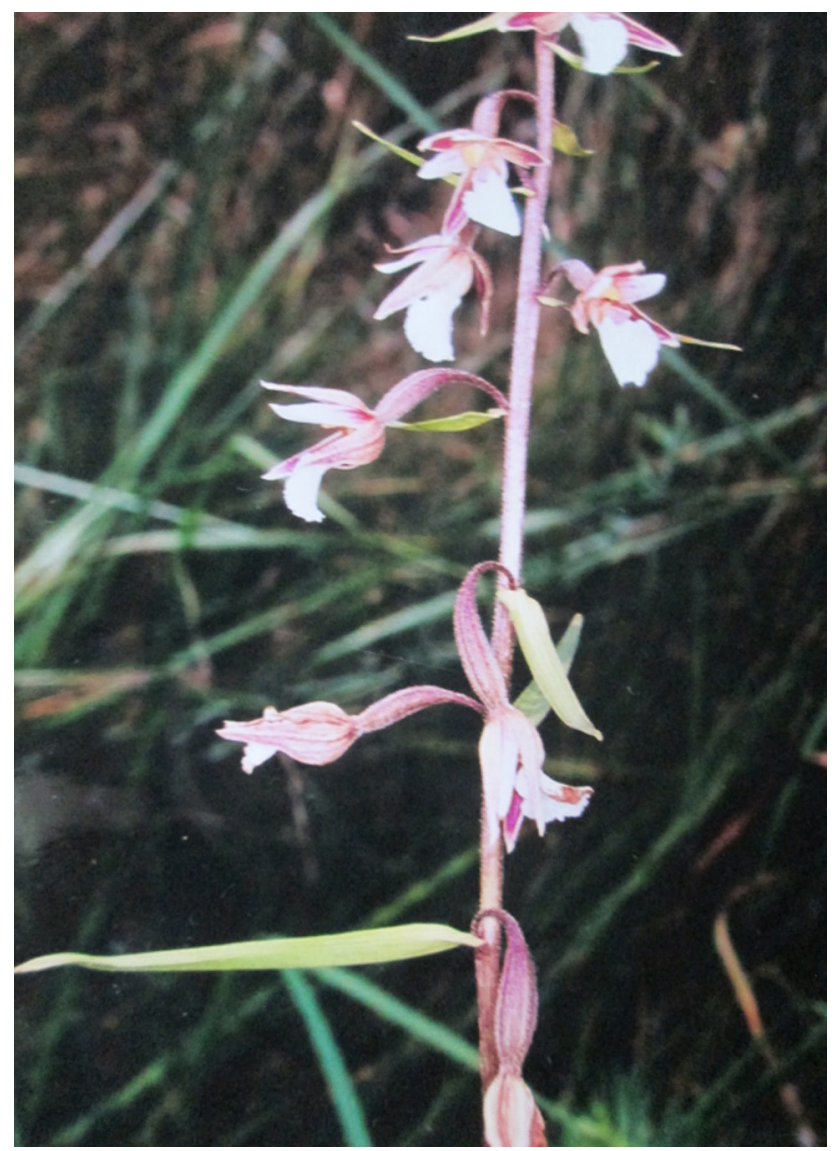

Fig. 5. An inflorescence of Epipactis palustris f. longibracteata with the lower bract longer than the ovary 


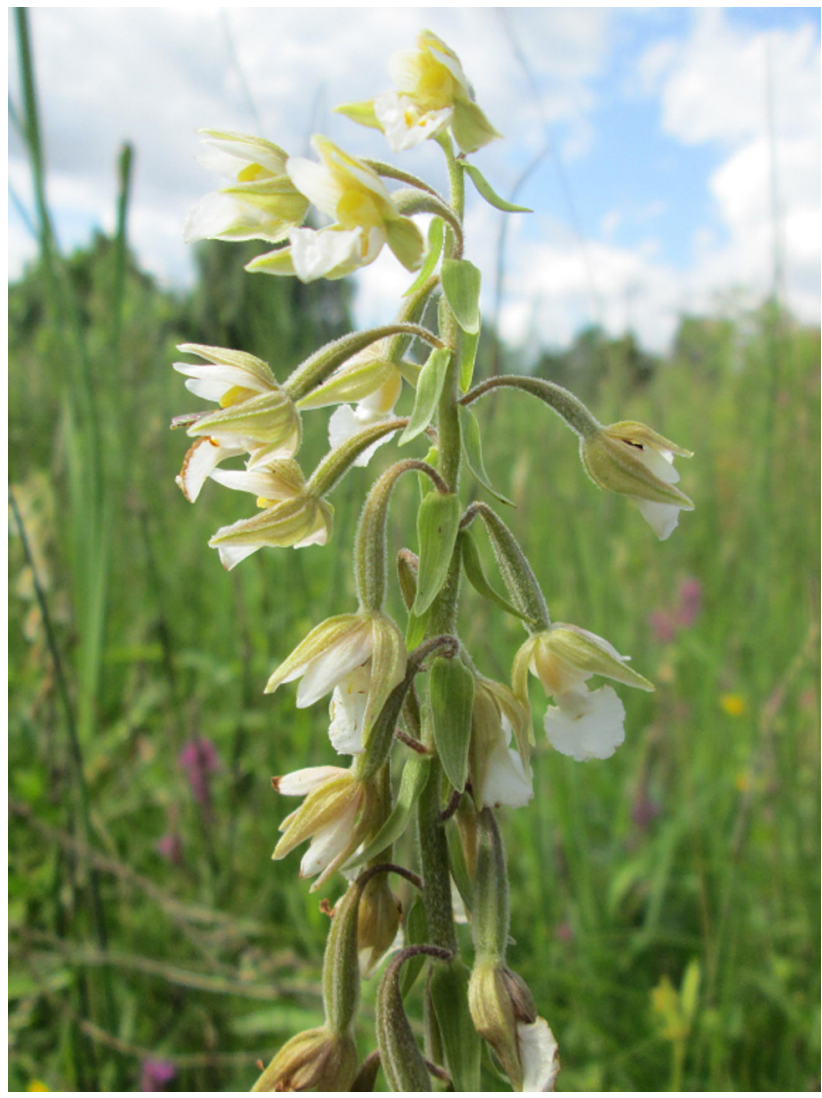

Fig. 6. Epipactis palustris f. ochroleuca

time on 30 randomly selected generative shoots, which are referred to in the text as ramets or plants. The following parameters were measured: the length of the aboveground shoot, the length of the inflorescence from the lowest bracteole, the length and width of the largest leaf as well as the length and width of the lowest bracteole, while the number of flowers in the cluster and the number of leaves were recorded. Moreover, the area covered by that population was also determined. Obtained results were subjected to basic statistical analyses (KaLA 2009). The arithmetic mean, median, variance, standard deviation and the coefficient of variation were calculated and the minimum and maximum values were determined. The one-way analysis of variance ANOVA was applied using the Statistica 10 programme in order to investigate the significance of differences between values of these traits. The significance for the means of recorded results was analysed using the LSD test. Moreover, normal distributions for plant height were given (SNEATH \& SOKAL 1973). The analyses were based on individual traits rather than group traits, because at present this population is located on private premises.

\section{RESULTS}

The locality is situated in the Wielkopolska National Park, south of forest compartment no. 209 Uroczyska Łódź (AtPol square BD17) in the vicinity of the
Mieliniec pond. Marsh helleborine is found on a moist meadow in the Molinietum medioeuropaeum (W. Koch 1926) association together with characteristic species of this association, i.e. Molinia caerulea and Dianthus superbus (Fig. 1). This population is located at the pond shore and its area in both years of observations was approx. $200 \mathrm{~m}^{2}$.

In the first year of the observations (2015) investigated plants had slightly longer shoots and inflorescences than in the next vegetation season. They also had slightly greater numbers of flowers and leaves. In 2016 analysed ramets had longer and wider leaves and longer bracteoles. The mean width of bracteoles was identical in both years of the study (Table 1, Fig. 2). In both years of the study the distribution of plants was close to normal, as evidenced by the predominance of medium-sized shoots (Fig. 3).

Values of the coefficient of variation for all analysed individual traits were relatively low. In both years the greatest variation was observed for the number of flowers in the inflorescence, the length of bracteoles and the length of inflorescences, while the number of leaves was the trait with the greatest stability (Table 1). The LSD test showed that in the years of this study only the width of the largest leaf differed statistically significantly at $\mathrm{p}<0.05$.

In the investigated marsh helleborine population three forms of this species were reported: $\mathrm{f}$. palustris and f. longibracteata, f. ochroleuca, (Figs 4-6), with the typical form, i.e., palustris being represented most numerously.

\section{DISCUSSION}

Marsh helleborine is a species, which as indicated by its name is associated with wet or moist habitats. Field observations as well as analyses under controlled conditions (WYRZYKIEWICZ-RAsZEWSKA et al. 2004, WyrZYKIEWICZ-RASZEWSKA 2006) show that it reaches its optimum, when an optimal amount of water is available; other conditions play a secondary role (apart from overgrowing by trees and shrubs, since it is also a heliophilous species). This is evidenced both by group characteristics of the population, such as population size, density, age structure, and individual traits, primarily plant height, the number of flowers in the inflorescence or the number and size of leaves. A comparison of individual traits at a 15-year interval shows that the population presently found on private premises is still in a good condition. The meticulous care of the property owners, which understand and appreciate the value of such botanical treasure and prevent encroachment of trees and shrubs needs to be highly praised.

Marsh helleborine is generally considered to be a relatively stable species (Hegr 1939, Meusel et al. 1965, Procházka \& Velísek 1983, Szlachetko \& Skakuj 1996); nevertheless, a total of 12 varieties or forms 
have been distinguished. In the discussed locality as many as three were reported, which obviously increases the value and importance of this population.

In comparison to the characteristics of the population prepared in 1999 and given in their study by AntKowiak \& PANKros (2000), at present the area covered by marsh helleborine decreased from $680 \mathrm{~m}^{2}$ to approx. $200 \mathrm{~m}^{2}$ Results obtained over 15 years ago for shoot length $(74.96 \mathrm{~cm})$ and leaf size (length of $14.68 \mathrm{~cm}$, width of $3.78 \mathrm{~cm}$ ) were very similar to those from the last two years of observations. In the late 1990's ramets were observed to have longer inflorescences (21.33). In turn, the number of flowers in the inflorescence was much greater in the last vegetation seasons (mean 21, while in 1999 mean 16). At present the number of leaves was slightly greater in comparison to 1999, amounting to 8.09 (Fig. 2).

It also needs to be stressed that in the area of E. palustris occurrence in the WNP a numerous population was reported also for the wasp spider (Argiope bruennichi), until recently a legally protected species.

\section{CONCLUSIONS}

At present the population is found in a good growth and development condition. No reduction of its area was observed in the course of this study.

The greatest threat to the existence of this heliophilous orchid would be overgrowing of its habitat, thus encroachment of trees and shrubs in that area needs to be prevented.

\section{ACKNOWLEDGEMENTS}

The study was supported by the Department of Botany, the Poznań University of Life Sciences.

\section{REFERENCES}

Antkowiak W., Pankros J. (2000): Charakterystyka ekologiczna populacji kruszczyka błotnego (Epipactis palustris (L.) Crantz) z Wielkopolskiego Parku Narodowego. Roczniki Akademii Rolniczej w Poznaniu 322, Botanika 3: 3-11.

Bilz M., Kell S.P., Maxted N., Lansdown R. V. (2011): European red list of vascular plants. Publications Office of the European Union, Luxembourg.

FiJAŁKowski D. (1994): Flora roślin naczyniowych Lubelszczyzny. Vol. 1. Lubelskie Towarzystwo Naukowe, Lublin.

Grulich V. (2012): Red List of vascular plants of the Czech Republic. Preslia 84: 631-645.

Hegi G. (1939): Illustrierte Flora von Mittel-Europa 2, Monocotyledones. J.F. Lehmanns Verlag, München-Berlin.

JACKOWiak B. (1993): Atlas rozmieszczenia roślin naczyniowych w Poznaniu. Prace Zakładu Taksono- mii Roślin UAM w Poznaniu 2. Bogucki Wydawnictwo Naukowe, Poznań.

Jackowiak B., Celka Z., Chmiel J., Latowski K., ŻuKOwsKi W. (2007): Red list of vascular flora of Wielkopolska (Poland). Biodiversity Research Conservation 5-8: 95-127.

JASIEWICZ A. (1981): Wykaz gatunków rzadkich i zagrożonych flory polskiej. Fragmenta Floristica et Geobotanica 27(3): 401-414.

Kala R. (2009): Statystyka dla przyrodników. Wydawnictwo Uniwersytetu Przyrodniczego w Poznaniu, Poznań.

KĄCKI Z., DAJDOK Z., SZCZĘ́́NIAK E. (2003): Czerwona lista roślin naczyniowych Dolnego Śląska. In: Z. Kącki (ed.). Zagrożone gatunki flory naczyniowej Dolnego Śląska. Instytut Biologii Roślin, Uniwersytet Wrocławski, Polskie Towarzystwo Przyjaciół Przyrody „Pro Natura”, Wrocław: 9-65.

KLuZa-Wieloch M., MaciejeWsKa-RutKowska I. (2015): Population of Epipactis palustris (L.) Crantz (Orchidaceae) in south-western part of Poznań. Steciana 19(4): 231-238.

KoRnAś J. (1976): Wymieranie flory europejskiej - fakty, interpretacje, prognozy. Phytocoenosis 5(3-4): 173-185.

KowALEWSKA J. (1995): Stan zachowania i formy zagrożeń Epipactis palustris (L.) Crantz na terenie Pobrzeża i Pojezierza Kaszubskiego. Badania Fizjograficzne nad Polską Zachodnią, Ser. B, Botanika 44: 173-177.

Meusel H., JäGer E., Weinert E. (1965): Vergleichende Chorologie der Zentraleuropäischen Flora. Gustav Fischer Verlag, Jena.

Michalik S. (1975): Storczyki - ginąca grupa roślin. Wiadomości Botaniczne 19(4): 231-241.

NowaK A. (2002): Epipactis palustris (L.) Crantz. In: A. Nowak, K. Spałek (eds). Czerwona księga roślin województwa opolskiego. Rośliny naczyniowe wymarłe, zagrożone, rzadkie. Wyd. Śląskie, Opole.

Pię́oś-Mirkowa H., Mirek Z. (eds) (2003): Atlas roślin chronionych. Multico, Warszawa.

ProcházKa F., Velísek V. (1983): Orchideje naši přirody. Ceskoslovenska Akademie Ved, Praha.

RozPoRZĄDZENIE Ministra Środowiska z dnia 9 października 2014 r. w sprawie ochrony gatunkowej roślin. (2014). Dziennik Ustaw RP poz. 1409.

Sarosiek J. (ed.) (1985): Studia nad ekologią roślin wyższych z Dolnego Śląska. Part 1. Acta Universitatis Wratislaviensis 637, Ser. Prace Botaniczne 28.

SAROSIEK J. (1990): Current problems concerning ekology and biology of orchids. In: J. Sarosiek (ed.). Proceedings of the Symposium on Biology and Ecology of European Ochids. Karpacz, May 30-June 3, 1985. Acta Universitatis Wratislaviensis 1055: 5-10. 
SNEATH P.H.A., Sokal R.R. (1973): Numerical taxonomy: the principals and practice of numerical classification. Freeman, San Francisco.

SzLAChetKo D.L. (1995): Zagrożenia gatunków z rodziny Orchidaceae na Pomorzu Zachodnim. In: W. Żukowski, B. Jackowiak (eds). Ginące i zagrożone rośliny naczyniowe Pomorza Zachodniego i Wielkopolski. Prace Zakładu Taksonomii Roślin UAM w Poznaniu 3. Bogucki Wydawnictwo Naukowe, Poznań: 123-126.

Szlachetкo D.L., Skakuj M. (1996): Storczyki Polski. Wyd. Sorus, Poznań.

Timchenko I.A., KUZIARIN O.T. (2009): Epipactis palustris (L.) Crantz. In: Ya.P. Didukh (ed.). Red data book of Ukraine. Vegetable kingdom. Global Consulting, Kiev.

WyRZYKIEWICZ-RASZEWSKA M. (2006): Struktura populacji kruszczyka błotnego Epipactis palustris (L.) Crantz na siedlisku antropogenicznym i siedliskach naturalnych Poznania i okolic. Typescript. $\mathrm{PhD}$ thesis. Uniwersytet Przyrodniczy w Poznaniu.

Wyrzykiewicz-Raszewska M., KieŁczewska H., MolińSKI K. (2004): Siedlisko a kondycja roślin kruszczyka błotnego Epipactis palustris (L.) Crantz. Colloquium Biometryczne 34a: 305-316.
ZająC A., ZająC M. (eds) (2001): Distribution atlas of vascular plants in Poland. Laboratory of Computer Chorology, Institute of Botany, Jagiellonian University, Kraków.

ZARZYCKI K., SzelĄG Z. (2006): Red list of the vascular plants in Poland. In: Z. Mirek, K. Zarzycki, W. Wojewoda, Z. Szeląg (eds). Red list of plants and fungi in Poland. W. Szafer Institute of Botany, Polish Academy of Sciences, Kraków.

Żuкошsкi W. (1976): Zanikanie storczyków w Polsce Niżowej w świetle analizy obecnego rozmieszczenia wybranych gatunków. Phytocoenosis 5(3/4): 215-226.

ŻuKowski W., JAcкоwiak B. (eds) (1995): Ginące i zagrożone rośliny naczyniowe Pomorza Zachodniego i Wielkopolski. Prace Zakładu Taksonomii Roślin UAM w Poznaniu 3. Bogucki Wydawnictwo Naukowe, Poznań.

For citation: KLUZA-WIELOCH M., WyrZYKIEWICZ-RASZEWSKA M. (2016): Current status of the population of Epipactis palustris (L.) Crantz (Orchidaceae) in the Wielkopolska National Park. Steciana 20(4): 201-207. doi: 10.12657/steciana.020.021 